\title{
Helping Students Get to Where Ideas Can Find Them
}

\section{Citation}

Duckworth, Eleanor. 2009. Helping Students Get to Where Ideas Can Find Them. New Educator 5, no. 3: 185-188.

\section{Published Version}

http://www1.ccny.cuny.edu/prospective/education/theneweducator/upload/1st_article.pdf

\section{Permanent link}

http://nrs.harvard.edu/urn-3:HUL.InstRepos:4449111

\section{Terms of Use}

This article was downloaded from Harvard University's DASH repository, and is made available under the terms and conditions applicable to Open Access Policy Articles, as set forth at http:// nrs.harvard.edu/urn-3:HUL.InstRepos:dash.current.terms-of-use\#OAP

\section{Share Your Story}

The Harvard community has made this article openly available.

Please share how this access benefits you. Submit a story.

Accessibility 


\title{
Helping Students Get to Where Ideas Can Find Them
}

\author{
ELEANOR DUCKWORTH \\ Harvard University, Cambridge, MA, USA
}

Winnie the Pooh said, of the hums that came to him from time to time, "Poetry and hums aren't things which you get. They're things which get you. And all you can do is to go where they can find you" (Milne, 1928/2007, p. 173). This journal issue is about helping students get their minds, their awareness, and their feelings so active and thoughtful and informs that they are in a place where hums-or connections, understandings, new ideas — can find them.

I start with a brief story. My colleague Alythea McKinney and I were presenting some of her work to a group of research educators. She described engaging fifth and sixth graders in a critical exploration (see Cavicchi et al., 2009) of documents pertaining to butter making in the United States at the end of the 19th century and the beginning of the 20th. These children had been examining original historical texts and images, and forming ideas about how U.S. farmers and their families might have experienced the Industrial Revolution; and they were taking those ideas further through drawing and writing about them, through considering each other's thoughts and drawings, and through examining further documents that McKinney offered them (McKinney, 2008).

Our audience was interested, engaged, and impressed with the student work. But we had presented the work as an example of critical exploration, our particular approach to curriculum and teaching, and near the end of the session one member of the audience asked us what was unique about what we were doing. She recognized that the children whose work we presented are working together, that they are provided well selected resource materials, that they create artwork in the interests of

Address correspondence to Eleanor Duckworth, Harvard University, Cambridge, MA, USA. E-mail: duckwoel@gse.harvard.edu

(@) Readers are free to copy, display, and distribute this article, as long as the work is

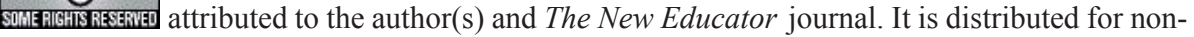
commercial purposes only, and no alteration or transformation is made in the work. More details of this Creative Commons license are available at http://creativecommons.org/licenses/by-nc-nd/3.0/. All other uses must be approved by the author(s) or The New Educator. The New Educator is published by the School of Education at The City College of New York. 
deepening understanding, that productive class discussions take place, and that the teacher's questions are open-ended. All of these are excellent practices, and this work showed fine examples of all of them, she observed. But these practices are all widely acknowledged already as contributors to first-rate teaching. What is original about what we do?

We believe that what is original is our two-sided approach: how we use our own subject matter knowledge, as curriculum planners and as teachers; and how we focus on the students' thoughts rather than our own.

First, we aim to put the learners in direct contact with the subject matter. When I was a member of the staff of the Elementary Science Study, at the beginning of my work in education, I was a newcomer both to science and to curriculum development. I was captivated by my colleagues' approach. They were not interested in giving students words about the physical and natural worlds - air pressure, transfer of energy, tropism. They wanted to give the kids the subject matter itself - earthworms, pendulums, ice cubes, balance beams, seeds - whatever it was. This brought the teaching and learning to life. It caught the interest and the imagination of the children. (And, I must say, caught my own — as a beginner in these matters at the time.) It also set up the subject matter as the source of authority - without the need for the teacher as intermediary. Did the bulb light or not? Did the bean seed need soil or not?

In our current work with critical exploration, the subject matter might be a poem, or historical documents, or an arithmetic problem, or some writing that needs punctuating. In every case, we have sought to develop ways to keep students attending closely to the material we present them, taking their own thoughts about it deeper, attending to each other's thoughts, generating more questions that we can respond to with yet further elements of subject matter.

In so doing, we find that contributing our own ideas and thoughts about the subject matter almost always short-circuits the students' thoughts, and decreases their interest. But when we help them to take charge of their own explorations of subject matter, they do remarkable work.

The second aspect of our approach also has its origins in an earlier experience of mine. When I was a research assistant with Jean Piaget and his colleague Barbel Inhelder, our aim was to not to teach, but to come to understand how children are seeing things. It served no purpose to us as researchers to give the children hints about what we wanted them to think-we would not have learned about their thinking. So we practiced how to get children talking about their thoughts on various matters, and we practiced how not to influence what they said, as they were saying it. And I found that the more interest I took in what they were saying, the more interest the children themselves took. I saw that they were willing-even eager- to keep thinking about the question, and to work on developing a degree of understanding that they found increasingly more satisfactory.

Now, as teachers in classrooms, we find again that when we are interested in the learners' thoughts, the learners take a deepening interest in their own thoughts, too. 
We find that we focus on the learners' thoughts rather than on our own, as the engine for what generates the intellectual life of the classroom. In part this is because the learners think better that way; and in part because it is by paying attention to what they are thinking and doing that we as teachers can see how next to call on our knowledge of the subject matter - what resources to provide, what next questions to ask.

These two aspects of how we use our knowledge make for a powerful way to help people learn: depend on carefully selected aspects of the subject matter, and listen carefully to the learners' ideas about them.

Teaching from the point of view of critical exploration can be complex, and is often very different from what a teacher is usually expected to do. For example, we try to engage in interesting questions without having a particular solution or class of solutions in mind; we do not use our knowledge to resolve differences, and determine a shared conclusion. As another example, we often introduce into the classroom, activities ideas, and materials that look like tangents, which we do in the interests of widening rather than narrowing the subject and the students' engagements with it.

The articles in this issue illustrate both the complexity and our often surprising modes of response. Their narratives demonstrate the different ways that the teachers/ authors call on their knowledge, while not taking over the work that is legitimately the students' work, nor taking over the authority that is legitimately the students' authority. The articles bear a careful reading, to see how the counter-intuitive responses on the part of the teachers do lead to further learning on the part of the students. In this collection, Cavicchi (2009) in physics, Chi (2009) in Chinese brush work, and McDonnell (2009) in the teaching and learning of elementary science use their knowledge to keep the students connected to the subject matter, whether by knowing what resources to call on next, or by keeping attention on a phenomenon that merits more thought, or by proposing a question that might further students'engagement.

The three teacher/authors whose work appears in this issue are exceedingly present in their teaching. They pay close attention to what their students are doing and saying, and they respond with further materials, appreciations, questions, and wonderings. The teachers do not put themselves between the subject matter and the learners - do not try, through telling or showing, to persuade the learners to see things as the teachers themselves see them. Instead, the teachers respect the learners' thoughts and encourage them to have more-knowing that students' ideas will evolve as the learners keep thinking and experiencing more aspects of the subject matter. In these articles, a careful reading of the teachers' dialogues with learners will reveal the many ways in which the teachers support the students' sense of their own capacities - the only thing that will continue to take the students' learning further. (The reader will also see that the teachers have their own struggles, as they strive to keep open their range of responsiveness to their students' work.) 
Without an external authority to be the judge of their thoughts, without the anticipation of an outside censor, the learners develop their own ability in making judgments. As McDonnell writes, "Students see the structures of the world and realize their capacities as sense-makers..." (McDonnell, 2009).

These teachers/authors know their subject matters deeply, and have spent time developing materials and activities to further the students' engagement. It is too much to expect every teacher to take this on. But this is what curriculum development should be - and, in the cases documented here, is. With the work described in these articles, readers are provided with both structures and details for teaching these subject matters in similar exploratory ways. And if readers have interest in and time for developing curriculum, in other areas, perhaps these examples can be of help. (See also Duckworth, ed., 2001)

We find that critical exploration in the classroom can help students to become deeply familiar with many aspects of a subject matter, and to feel at home with it, and open to new ways of thinking about it - open to what I have called "the having of wonderful ideas" (Duckworth, 1973, 2006). Nobody can force themselves to get poems or hums - or to have new ideas. Much less can someone force learners to have thoughts they haven't had before. But if we cannot force them, we can ready them-we can get them to a place where new ideas can find them.

\section{REFERENCES}

Cavicchi, E. (2009). Exploring mirrors, recreating science and history, becoming a class community. The New Educator, 5(3), 249-273.

Cavicchi, E., Chiu, S.-M., \& McDonnell, F. (2009). Introductory paper on critical explorations in teaching art, science, and teacher education. The New Educator, 5(3), 189-204.

Chiu, S. (2009). "The ancient master painted like me". The New Educator, 5(3), 229-248.

Duckworth, E. (2001) "Tell me more": Listening to learners explain. New York: Teachers College Press.

Duckworth, E. (2006). The having of wonderful ideas. In E. Duckworth (Ed.), “The having of wonderful ideas" and other essays on teaching and learning (pp. 1-14, 3rd ed.). New York: Teacher's College Press. (Original essay published in 1973).

McDonnell, F. (2009). "I wonder how this little seed can have so much potential": Critical exploration supports preservice teachers' development as science researchers and teachers. The New Educator, 5(3), 105-228.

McKinney, A. (2008). The Industrial Revolution and the revolution of Social Studies: A visual record of an original student investigation. Critical Explorers, Inc., http://criticalexplorers.org/curricularNarrative/IRandRevSocStudies.pdf

Milne, A. A. (2007). The house at Pooh corner. London: Egmont. (Original book published in 1928). 